\title{
PENERAPAN SISTEM DEMOKRASI \\ DALAM MENJAGA PERSATUAN DAN KONSTITUSI \\ SERTA PENEGAKAN HUKUMNYA
}

\author{
Ronny Winarno \\ Universitas Merdeka Pasuruan
}

\begin{abstract}
Abstrak
Demokrasi pantas menjadi panutan di era reformasi, karena dengan demokrasi setiap orang dapat menyampaikan aspirasi, melakukan bargaining politik, memperoleh kekuasaan termasuk sebagai alat menyampaikan mosi tidak percaya. Bahkan Mahkamah Konstitusi RI dalam setiap putusannya, cermatannya, pertimbangan hukumnya senantiasa dijiwai demokrasi. Senyatanya sistem demokrasi diharapkan mampu menjaga persatuan bangsa dan keutuhan konstitusi.
\end{abstract}

Kata kunci: demokrasi, konstitusi, penegakan hukum

\begin{abstract}
The democration reasonable as a norm in reformation era, because with democration every body can the expression and good idea, bargaining of politics, to take authority including as an expression of bad opinion. And so for Council of Constitution RI on the decision, reasoning, consideration of law always to protect of democration. A reality in the system of democration an hopely is capable of the nation and constitution.
\end{abstract}

Keywords: democracy, constitution, law enforcement

\section{A. PENDAHULUAN}

Sistem demokrasi yang tergambar dalam kehidupan bangsa Indonesia yang direfleksikan dalam pemerintahan negara RI telah berlangsung bertahun-tahun dengan berbagai fenomenanya yang dalam implementasinya tertuliskan dan dimaknakan ".....dari rakyat, oleh rakyat dan untuk rakyat...." Demokrasi secara klasik sudah dipahami secara universal berasal dari kata "demos" (rakyat) 
dan "kratien atau kratos" (kekuasaan). ${ }^{1}$ Maksudnya dalam suatu negara demokrasi, kedaulatan sebagai kekuasaan tertinggi itu berada di tangan rakyat. Kekuasaan tertinggi yang berada di tangan rakyat ini dapat mencakup bidang politik (demokrasi politik) atau bidang ekonomi (demokrasi ekonomi). ${ }^{2}$

Prinsip demokrasi yang demikian itu merupakan pijakan awal dari pendidikan politik yang harus dipahami dalam perspektif kebangsaan dan kenegaraan untuk melihat dan mengkritisi kinerja dan produk lembaga politik baik suprastruktur (legislatif, eksekutif dan yudisial) maupun infrastruktur (partai politik, tokoh politik, kelompok penekan, kelompok kepentingan). ${ }^{3}$ Demokrasi yang dianut dan dijalankan oleh bangsa Indonesia secara filsafati telah ditegaskan dalam Pembukaan UUD NRI 1945 yang secara substansial mencakup adanya hak hidup bangsa dan menghapuskan penjajahan, mewujudkan kemerdekaan, adanya keyakinan atas ketuhanan dan cita-cita luhur yang kemudian dibentuklah pemerintahan Indonesia yang merdeka, bersatu, berdaulat, adil dan makmur.

Melihat pada pola pikir bangsa Indonesia yang demikian itu menunjukkan, bahwa di Indonesia tela1h dibangun dan melaksanakan sistem demokrasi yang sesuai dengan jiwa bangsa dengan pandangan hidupnya (way of life) yakni demokrasi Pancasila. Bahkan karakteristik dan hakekat demokrasi telah menjadi perekat dicetuskannya Sumpah Pemuda tanggal 28 Oktober 1928 sebagai tonggak kebangkitan generasi muda bangsa Indonesia untuk mewujudkan suatu negara yang merdeka, bersatu, berdaulat, adil dan makmur dengan kesejahteraan bangsa yang dicitakannya.

Nilai demokrasi dalam Sumpah Pemuda juga didengungkan terus yang kemudian terbentuklah nilai-nilai kepahlawanan yang secara fisik, moral, lahir dan batin tergunakan sebagai senjata yang secara heroik mampu mengoyak dan merontokkan kekejaman penjajahan baik yang dilakukan penjajah maupun beberapa anggota masyarakat bangsa Indonesia sendiri yang diperalat oleh

\footnotetext{
${ }^{1}$ Miriam Budiardjo, Dasar-Dasar Ilmu Politik, Jakarta: Gramedia, 1980, hlm. 69-73 dan h. 104105

2 Jimly Asshiddiqie, Gagasan Kedaulatan Rakyat Dalam Konstitusi dan Pelaksanaannya di Indonesia, Jakarta: Intermasa, 1994, hlm. 25

3 Toni Adrianus Pito, Mengenal Teori-Teori Politik, Dari Politik Sampai Korupsi, Bandung: Nuansa, 2006, hlm. 45
} 
penjajah untuk menindas bangsanya sendiri, yang kemudian banyak dikenal dengan semangat kepahlawanan dan dikenang sebagai Hari Pahlawan (10 Nopember).

Pergulatan kepentingan politik, perseteruan kelompok, persaingan partai politik termasuk konkurensi kekuasaan yang cenderung membabi buta seperti yang terjadi sekarang ini dan lain lain permasalahan yang menggunakan dalih demokrasi, padahal dalam kenyataannya hanya untuk memenuhi kepentingan sesaat. Apalah jadinya, demokrasi dijadikan kambing hitam dalam mengekspresikan kepentingan-kepentingan, yang apabila hal ini berlangsung terus menerus tanpa ada filter dan proteksi yang mampu mengontrol dan mencegah, maka akan terjadi dampak negatif pada persatuan bangsa dan konstitusi negara, bisa dibayangkan akan merusak moral dan jiwa bangsa Indonesia.

Untuk itulah makna penting yang harus ditegakkan adalah bagaimana menerapkan sistem demokrasi yang tepat dan benar serta "pener" dalam menjaga persatuan dan konstitusi khususnya di daerah tingkat Kabupaten/Kota yang masih rentang konflik demokrasi karena kurang memahami sistem demokrasi.

\section{B. DEMOKRASI DAN JAMINAN KONSTITUSI}

Penerapan sistem demokrasi di Indonesia harus tetap berpegangan dan berpedoman secara teguh pada Pancasila dan UUD NRI 1945 sebagai bentuk jaminan konstitusi bangsa Indonesia untuk mempertahankan kedaulatan dan persatuan bangsa. Nilai-nilai sumpah pemuda dan nilai-nilai kepahlawanan harus selalu menjadi indikator penerapan sistem demokrasi yang tidak mudah terkontaminasi oleh pengaruh globalisasi dan tetap mempertahankan jati diri bangsa Indonesia guna mencapai tujuan negara serta menjaga persatuan dan konstitusi bangsa.

Jaminan konstitusi yang mencakup tentang persatuan bangsa telah ditegaskan dalam Pasal 1 UUD NRI Tahun 1945 yang menyatakan sebagai berikut :

(1)Negara Indonesia adalah negara kesatuan yang berbentuk Republik.

(2)Kedaulatan berada di tangan rakyat dan dilaksanakan menurut Undang undang Dasar. 
(3)Negara Indonesia adalah negara hukum.

Apabila mencermati Pasal 1 UUD NRI 1945 ini terlihat bahwa sistem demokrasi telah tersurat dalam pasal tersebut dan harus dilaksanakan dengan mendasarkan pada kepribadian bangsa yang bertujuan untuk menjaga persatuan dan konstitusi negara.

Jelas sekali jaminan konstitusi yang ada tersebut, mampu membentuk nilainilai sumpah pemuda dan nilai kepahlawanan yang dapat menjadi landasan berdemokrasi dan mempertahankan persatuan bangsa dan mempertahankan berlangsungnya konstitusi negara RI.

Aspek filsafati dalam jaminan konstitusi tersebut terlihat, negara kita memiliki cita-cita luhur menjadi masyarakat dan negara yang sejahtera (welfare state) dengan sistem pemerintahannya yang baik dan mengedepankan kepentingan masyarakat (good gouvernment $)^{4}$ adalah yang didambakan dan diangankan masyarakat Indonesia. Oleh karena itu beberapa asas yang dianut oleh UUD NRI Tahun 1945 meliputi asas-asas sebagai berikut :

1. Asas Pancasila;

2. Asas kekeluargaan;

3. Asas kedaulatan rakyat;

4. Asas pembagian kekuasaan; dan

5. Asas negara hukum. ${ }^{5}$

Makna yang lebih penting, bahwa prinsip-prinsip demokrasi selalu mendasari dalam berbagai interaksi masyarakat dalam mengaplikasikan berbagai kepentingan dalam kehidupan bermasyarakat berbangsa dan bernegara. Sistem demokrasi dalam sejarahnya juga digunakan sebagai kesepakatan luhur bangsa

\footnotetext{
${ }^{4}$ Lihat ketentuan asas-asas penyelenggaraan negara dalam UU No. 28 Tahun 1999 yang meliputi asas kepastian hukum, asas tertib penyelenggaraan negara, asas kepentingan umum, asas keterbukaan, asas proporsionalitas, asas profesionalitas dan asas akuntabilitas.

Bandingkan pula dengan pasal 20 UU No. 32 Tahun 2004 tentang pemerintahan daerah yang menegaskan tentang asas penyelenggaraan pemerintahan yang berpedoman pada asas penyelenggaraan negara yang meliputi asas kepastian hukum, asas tertib penyelenggaraan negara, asas kepentingan umum, asas keterbukaan, asas proporsionalitas, asas profesionalitas, asas akuntabilitas, asas efisiensi dan asas efektifitas.

${ }^{5}$ Kusnardi \& Harmaily Ibrahim, Pengantar Hukum Tata Negara, Jakarta: Pusat Studi HTN Fak. Hukum UI dan CV Sinar Bakti, 1988, hlm. 101-164
} 
Indonesia ketika membentuk negara kesatuan yang berbentuk Republik yang kemudian dijabarkan pula dalam sistem pemerintahannya dengan dibentuknya pemerintahan daerah sebagaimana Pasal 18 UUD NRI Tahun 1945. Sehingga makna sistem demokrasi dalam konteks negara yang berbentuk Republik, adalah sebagai pedoman dalam bermasyarakat, berbangsa dan bernegara.

Tentulah dalam kondisi ini di Indonesia tidak cocok untuk dibentuk sistem yang lain selain sistem demokrasi. Pengalaman sejarah sudah berkali-kali terjadi berbagai tindak dan gerakan yang bersifat menentang dan memusuhi demokrasi yang ada di Indonesia termasuk akan mengganti dasar negara Pancasila dan UUD NRI Tahun 1945 seperti peristiwa G30S/PKI dan lain-lain, namun semuanya kandas, Pancasila tetap terjaga dan eksis sehingga kedaulatan negarapun juga tetap terjaga.

Implementasi dalam sistem demokrasi juga dimunculkan bagaimana penyelenggaraan pemerintahan yang didasarkan kedaulatan rakyat, sehingga rakyat sepenuhnya memiliki hak untuk menentukan perkembangan kenegaraan berdasarkan ketentuan perundang-undangan. Oleh sebab itu dalam pelaksanaan sistem pemerintahan ini demokrasi memberikan pemberlakuan asas kesamaan di dalam hukum dan pemerintahan (equality before the law) sebagaimana dalam Pasal 27 ayat (1) UUD NRI 1945 yang menyatakan: "Segala warga negara bersamaan kedudukannya di dalam hukum dan pemerintahan dan wajib menjunjung hukum dan pemerintahan itu dengan tiada kecualinya."

Termasuk pula dalam rangka sistem demokrasi untuk mewujudkan tatanan hukum yang baik, peran sistem demokrasi menjadi dasar pijakan untuk mengkonstruksikan secara rasional dalam mereformasi masyarakat. Oleh sebab itu bertolak dari kenyataan kemasyarakatan dan situasi kultural di Indonesia serta kebutuhan riil masyarakat, maka menurut Mochtar Kusumaatmadja perlu landasan atau kerangka teoretis bagi pembinaan hukum nasional dengan mengakomodasikan pandangan tentang hukum dari Eugen Ehrlich dan teori hukum Rouscou Pound yang memandang hukum sebagai sarana pembaharuan serta sarana untuk menjamin ketertiban dan kepastian hukum. 
Dengan konsep hukum yang demikian itu, Mochtar Kusumaatmadja ${ }^{6}$, memandang tatanan hukum sebagai suatu sistem yang tersusun atas tiga komponen (sub sistem), yaitu:

1. Asas-asas dan kaidah-kaidah hukum;

2. Kelembagaan hukum; dan

3. Proses perwujudan hukum.

Mengenai asas-asas dan kaidah-kaidah hukum adalah terkait dengan suatu aturan yang mengandung nilai-nilai tentang kebenaran dan keadilan yang bersifat kodrati atau universal dan hakiki. Dimaksudkan disini nilai-nilai (norma) yang terkandung tersebut merupakan sari dari suatu idea hukum (recht idee) yang diharapkan mampu digunakan sebagai pedoman mengatur suatu kondisi dalam masyarakat dengan maksud agar tercipta ketertiban dalam masyarakat, serta terbentuknya hak dan kewajiban yang seimbang, dan dapat dilaksanakannya pedoman tersebut oleh semua pihak serta mampu memberikan kepastian hukum, kemanfaatan hukum dan keadilan.

Suatu peraturan hukum memiliki jantung peraturan yang berupa asas hukum, oleh karena itu asas hukum merupakan: (1) landasan yang paling luas bagi lahirnya suatu peraturan hukum atau merupakan ratio legi dari peraturan hukum; (2) sarana yang membuat hukum itu hidup, tumbuh dan berkembang dan menunjukkan hukum itu bukan sekedar kumpulan peraturan belaka, karena asas hukum mengandung nilai-nilai dan tuntutan-tuntutan etis; (3) jembatan antara peraturan hukum dengan cita-cita sosial dan pandangan/tuntutan etis masyarakat. ${ }^{7}$

Demikian pula dengan kelembagaan hukum yang sangat diperlukan dalam menunjang proses implementasi hukum dalam berbagai kepentingan yang mampu menegakkan hukum dalam mencapai derajat keadilan bagi seluruh masyarakat. Pada akhirnya proses perwujudan hukum akan terbentuk senada dengan kemanfaatan nilai-nilai yang terkandung dalam suatu aturan, sebagaimana pendapat Satjipto Rahardjo yang menyatakan sebagai berikut: ${ }^{8}$

6 Mochtar Kusumaatmadja, Pembinaan Hukum Dalam Kerangka Pembangunan Nasional, Bandung: Binacipta, 1986, hlm. 11

${ }^{7}$ Satjipto Rahardjo, Ilmu Hukum, Bandung: Citra Aditya Bakti, 2006, hlm. 45

${ }^{8}$ Ibid, hlm. 13 
masyarakat dan ketertibannya merupakan dua hal yang berhubungan sangat erat, bahkan bisa juga dikatakan sebagai dua sisi dari satu mata uang. Susah untuk mengatakan adanya masyarakat tanpa ada suatu ketertiban, bagaimanapun kualitasnya. Kendati demikian segera perlu ditambahkan di sini, bahwa yang disebut sebagai ketertiban itu tidak didukung oleh suatu lembaga yang monolitik. Ketertiban dalam masyarakat diciptakan bersamasama oleh berbagai lembaga secara bersama-sama, seperti hukum dan tradisi. Oleh karena itu dalam masyarakat juga dijumpai berbagai macam norma yang masing-masing memberikan sahamnya dalam menciptakan ketertiban itu. Perlu direnungkan dan dicermati pula, bahwa hukum bukanlah satu-satunya lembaga yang menciptakan ketertiban dalam masyarakat.

Hakekat nilai-nilai yang ada dari suatu aturan tersebut terjadinya diawali dengan gagasan untuk membuat suatu aturan dengan cara memperhatikan berbagai tatanan yang berlaku dalam masyarakat. Tatanan dimaksud tercermin dan dilaksanakan dalam keseharian masyarakat dan dikenal sebagai suatu kebiasaan. Bilamana kebiasaan ini dilakukan setiap hari, dipatuhi serta acapkali dilengkapi dengan sanksi moral dan sanksi lain yang bersifat ringan dan berhubungan dengan tata krama, maka kebiasaan ini bisa berkembang kepada masyarakat lainnya yang lambat laun menjadi hukum kebiasaan. Selanjutnya hukum kebiasaan ini dipatuhi oleh beberapa kelompok masyarakat akan menjadi adat dan bisa meningkat menjadi hukum adat. Kelak tatanan nilai-nilai ini akan menjadi sumber hukum dan menjadi hukum positif (ius constitutum) yang berlaku bagi seluruh masyarakat dengan segala konsekwensi hukumnya.

\section{PENERAPAN SISTEM DEMOKRASI DALAM MENJAGA PERSATUAN DAN DEMOKRASI}

Implementasi sistem demokrasi yang sudah berlangsung selama ini bila dikaitkan dengan tujuan pembentukan Negara Kesatuan Republik Indonesia, jelas sekali peran penting masyarakat Indonesia harus mampu mewujudkan prinsip dasar dan nilai-nilai sumpah pemuda dan kepahlawanan guna menjaga persatuan dan konstitusi bangsa Indonesia. Persatuan bangsa harus terjaga dengan menerapkan sistem demokrasi yang tepat di antaranya dengan menitikberatkan pada aspek hukum yang dijadikan sebagai dasar dan legalitas dalam menyusun berbagai 
peraturan perundang-undangan termasuk di dalamnya bagaimana dalam pola penegakan hukumnya.

Dalam rangka menjaga konstitusi, ajang sistem demokrasi menjadi salah satu media untuk memotret, mengukur dan mengkaji serta melakukan proses mempertahankan konstitusi yang sudah dibentuk dan menjadi way of life bangsa Indonesia. Sangat riskan apabila dalam proses penerapan sistem demokrasi sudah terkontaminasi dengan berbagai kepentingan yang dapat merongrong semangat sumpah pemuda dan semangat kepahlawanan bilamana masyarakat tidak menyadari akan berbagai pengaruh globalisasi yang bisa menghancurkan bangsa.

Generasi muda sebagai penerus bangsa perlu memahami dan mengerti serta melaksanakan prinsip dan nilai semangat sumpah pemuda dan kepahlawanan yang diwujudkan untuk tetap bersatu dan tidak tercerai oleh kepentingan yang bersifat individu. Oleh sebab itu asas Pancasila, asas kekeluargaan, asas kedaulatan rakyat, asas pembagian kekuasaan dan asas negara hukum sebagai pijakan mendasar dalam menerapkan sistem demokrasi guna menjaga persatuan dan konstitusi negara.

Dalam realitanya peranan Mahkamah Konstitusi RI sangat besar sekali dan memberikan perubahan paradigma kepada masyarakat tentang betapa pentingnya mempertahankan konstitusi sebagai sarana mempertahankan kedaulatan bangsa serta mempertahankan keutuhan dan persatuan bangsa untuk menuju masyarakat yang adil dan sejahtera. Berarti Mahkamah Konstitusi RI telah membuat lompatan-lompatan "meaning of constitution" yang lebih memberikan hidayah dalam tata hukum modern yang banyak berpihak kepada keadilan, kemasyarakatan, kemashlahatan termasuk kontinuitas hukum yang hidup dalam masyarakat (living law).

Menurut Arief Sidharta, ${ }^{9}$ tata hukum modern selain bersifat ekspresif (mengungkapkan pandangan hidup, rasa keadilan dan nilai-nilai kultural lainnya) juga bersifat instrumental (merupakan sarana mencapai tujuan). Pendapat Arief Sidharta yang demikian itu sangat signifikan dengan lingkup produk-produk Mahkamah Konstitusi RI dan menjadi bagian yang tak terpisahakan dengan tujuan

\footnotetext{
${ }^{9}$ Arief Sidharta, Refleksi Tentang Struktur Ilmu Hukum, Bandung: Mandar Maju, 1999, hlm. 9
} 
bangsa Indonesia yang menginginkan terwujudnya kesejahteraan bangsa dan terlaksananya hukum sebagai panglima.

Dengan demikian, idealnya sistem demokrasi yang diterapkan harus tetap memperhatikan kepentingan bangsa dan negara serta tidak meninggalkan hakekat Pancasila, kedaulatan rakyat dan tatanan hukum yang diperlukan sebagai konsekwensi Indonesia adalah Rechtstaat.

Justru dalam proses penerapan sistem demokrasi inilah konsep hukum harus lebih jelas dan masyarakat harus mampu melaksanakan hukum dan menumbuhkan kesadarannya tentang pentingnya persatuan dan kedaulatan bangsa. Perlindungan dan jaminan hukum dalam konstitusi, yakni UUD NRI Tahun 1945 akan membantu menyiapkan komponen yuridis dalam mempertahankan persatuan bangsa dan konstitusi negara. Nurani dan kendala dalam proses sistem demokrasi harus selalu dikaji dan dilakukan pembinaan agar tidak terpengaruh oleh berbagai kepentingan yang bisa meruntuhkan nilai sumpah pemuda dan kepahlawanan yang pada akhirnya bisa mempengaruhi jiwa persa-tuan bangsa.

\section{PENEGAKAN HUKUM YANG BERKEADILAN DALAM SISTEM DEMOKRASI}

Penegakan hukum (law of enforcement) tidak bisa lepas dari rangkaian adanya kaidah hukum atau peraturan; aparat penegak hukum, fasilitas yang diperlukan dan kesadaran hukum masyarakat. ${ }^{10}$ Penegakan hukum pada prinsipnya sebagai upaya melaksanakan atau menerapkan aturan hukum sesuai dengan yang sudah ditetapkan. Dapat pula dikatakan merupakan penerapan yang serasi dari nilai-nilai dan kaidah-kaidah yang kemudian terwujud dalam pola perilaku. Selama belum ada kesadaran akan adanya pelbagai pengertian hukum, agaknya sukar sekali untuk mengalami adanya proses penegakan hukum yang baik, yang menurut beberapa kalangan berintikan pada keadilan atau kedamaian.

Prinsip dasar filsafati penegakan hukum telah ditegaskan dalam konstitusi kita, yaitu di dalam Pasal 27 ayat (1) UUD NRI 1945. Di berbagai pelosok negeri

${ }^{10}$ Soerjono Soekanto \& Mustafa Abdullah, Sosiologi Hukum Dalam Masyarakat, Jakarta: CV Rajawali, 1982, hlm. 14. 
ini banyak terbicarakan tentang proses penegakan hukum yang bertujuan bagaimana bisa menciptakan keadilan. Ketika proses penegakan hukum berlangsung acapkali terdapat berbagai kendala yang berakibat tenjadi konfrontasi antara aparat penegak hukum dengan masyarakat, antara masyarakat dengan kelompok masa, bahkan tidak jarang timbul konfrontatif antar institusi penegak hukum sebagai akibat perbedaan pandangan dan argumentasi tentang penegakan hukum yang telah berlangsung termasuk bagaimana hierarkhie proses pertanggungjawabannya, mengingat di dalamnya juga sarat dengan hak asasi manusia. Setiap proses penegakan hukum diperlukan kejelasan dan kedudukan kasuistisnya secara tepat dan proportif.

Berbagai amuk massa dan tindakan destruktif yang tidak terkendalikan sebagai akibat adanya proses penegakan hukum yang tidak sesuai dengan ketentuan hukum dan fakta hukum yang terjadi, pada akhirnya akan menciptakan sikap apatis atas hukum dan tidak memperhatikan nilai-nilai keadilan, kepastian hukum dan kemanfaatan hukum termasuk pula akan berpengaruh terhadap makna persatuan dan berlangsungnya eksistensi konstitusi negara RI.

Timpangnya penegakan hukum disebabkan karena beberapa faktor diantaranya karena adanya intervensi dari pihak tertentu seperti pihak-pihak yang berperkara atau pihak lain (provokator) yang mungkin berkepentingan dalam proses dimaksud (lihat kasus Anggodo, Gayus Tambunan, kasus priok dll kasus yang terjadi). ${ }^{11}$

Penegakan hukum sebagai refleksi demokrasi atas berbagai peraturan hukum yang harus dipatuhi oleh masyarakat dan seluruh penegak hukum agar aturan yang sudah ditetapkan bisa ditegakkan sesuai dengan tingkat penegakannya. Semua pihak harus menerima, memahami dan melaksanakan secara konsekwen atas proses penegakan hukum yang sudah sesuai dengan ketentuan perundangan yang berlaku.

Perihal proses penegakan hukum, secara asumtif dalam keseharian juga ada pelbagai macam pengertian yang timbul. Seperti seorang petugas yang setiap hari hidup dalam konteks ketertiban semata-mata akan menganggap, bahwa penegakan

${ }^{11}$ Jawa Pos, edisi Maret 2010 
hukum adalah identik dengan penegakan ketertiban semata-mata. Akibatnya, tanpa adanya penindakan, ketertiban tidak akan mungkin tegak.

Seorang warga masyarakat pedesaan yang sehari-hari hidup dalam sistem pergaulan tersebut, cenderung mempunyai anggapan yang kuat, bahwa suatu sengketa dapat diselesaikan menurut pola perilaku ajeg yang ada dan menghasilkan kedamaian. Dia merasa tidak perlu menyelesaikannya di pengadilan, oleh karena mungkin keputusan pengadilan menetapkan, ada pihak yang menang dan ada pihak yang kalah. Sehingga di kemudian hari pihak yang kalah akan menuntut kembali.

Kondisi yang demikian itulah yang tumbuh, berkembang dan diyakini masyarakat dalam interaksi kehidupannya. Demikian pula dalam mengamati pola proses penerapan hukum di masyarakat selain tampak adanya peraturan atau hukum yang tertulis dan ada hukum yang tidak tertulis yang dikatakan merupakan living law.

Semua pemahaman proses penegakan hukumnya mengarah menciptakan keadilan, berarti dalam implementasi penegakan hukum di masyarakat, unsur keadilan sebagai salah satu tujuan yang hendak dicapai.

Keadilan akan bersanding dengan kepastian hukum dan kemafaatan hukum. Menurut Gustav Radburch, sebagaimana disitir oleh Satjipto Rahardjo, ${ }^{12}$ bahwa hukum itu dituntut untuk memenuhi nilai-nilai dasar dari hukum, yaitu mengandung keadilan, kegunaan atau kemanfaatan dan kepastian hukum. Persoalan tujuan hukum yang didalamnya meliputi aspek kepastian hukum, keadilan dan kemanfaatan hukum, sampai dengan sekarang masih menjadi perdebatan terkait dengan essensi penegakannya, yakni mendahulukan dan mementingkan kepastian hukumnya atau keadilan ataukah kemanfaatannya.

Oleh karena itu tujuan akhir bernegara hukum adalah untuk menjadikan kehidupan rakyat dan bangsa ini bahagia, oleh karena itu menurut Satjipto, hukum yang tepat adalah hukum yang progresif, yaitu hukum yang mampu mengikuti perkembangan jaman, mampu menjawab perubahan jaman dan mampu melayani masyarakat dengan menyandarkan pada aspek moralitas dan sumber daya manusia

\footnotetext{
${ }^{12}$ Satjipto Rahardjo, Op.cit, hlm. 20
} 
penegak hukum itu sendiri. ${ }^{13}$ Sehingga di dalam proses penegakan hukum akan berlangsung bagaimana keadilan, kepastian hukum dan kemanfaatan hukum bisa seimbang dan memberikan kedamaian bagi seluruh komponen pelaksanaan penegakan hukum. Disinilah peranan Mahkamah Konstitusi di dalam mengawal persatuan bangsa dan keutuhan konstitusi sangatlah diperlukan dengan segenap kemampuannya untuk melakukan produk-produk hukum yang progresif.

Berdasarkan konsep penerapan sistem demokrasi dalam menjaga persatuan dan konstitusi serta penegakan hukumnya pada hakekatnya juga diperlukan dalam proses pembangunan hukum. Dalam proses pembangunan hukum, terdapat adanya politik hukum (rechts politiek) diantaranya menggunakan prinsip "law is a tool of social engineering", yang hal ini juga telah dipertegas dalam UU Nomor 25 Tahun 2000 tentang program pembangunan nasional (khususnya di bidang hukum). Senyatanya bahwa hukum juga berperan serta mendampingi kiprah politik dalam segala aspeknya terutama untuk memberikan legalitas dan kekuatan yuridisnya.

Dalam praktiknya, menurut Moh. Mahfud MD, demokrasi dan hukum ibarat dua sisi mata uang yang tidak dapat dipisahkan. Demokrasi tidak akan tegak jika tidak dikawal oleh hukum. Sebaliknya hukum tidak akan dapat ditegakkan dengan benar jika sistem politiknya tidak demokratis. Adapun ciri negara yang demokratis adalah, bahwa partai politik dan lembaga perwakilan rakyat memiliki peran yang sangat menentukan dalam penggarisan haluan negara, kebebasan pers relatif terjamin dan eksekutif (pemerintahannya) lebih meletakkan diri sebagai pelaksana keputusan lembaga perwakilan rakyat dan tidak intervensionis. ${ }^{14}$

Perlu diketahui pula, bahwa kekuatan politik acapkali mengintervensi di dalam peran dan fungsi hukum, sehingga konfigurasi politik berkembang melalui tolak-tarik antara yang demokratis dan otoritarian, sedangkan karakter produk hukum mengikutinya dalam tolak-tarik antara yang responsif dan yang konservatif. Sementara itu untuk membangun tertib hukum dan meminima-

13 Satjipto Rahardjo, Membedah Hukum Progresif, Jakarta: Kompas Media Nusantara, 2006, hlm.ix

${ }^{14}$ Moh. Mahfud MD, Hukum dan Pilar-Pilar Demokrasi, Yogyakarta : Gama Media, 1999, hlm. 186 
lisasikan pengaruh politik, judicial review sebenarnya bisa digunakan sebagai alat kontrol yang baik. ${ }^{15}$

Dengan demikian pendidikan politik lebih diharapkan agar komponen masyarakat mampu memahami makna sistem kehidupan bermasyarakat, berbangsa dan bernegara terutama dalam rangka berpartisipasi mewujudkan pemerintahan yang demokratis yang berpedoman pada essensi adanya akuntabilitas (tanggung jawab kepada rakyat), rotasi kekuasaan, rekrutmen politik yang terbuka, adanya Pemilu dan jaminan menikmati hak dasar (asasi). ${ }^{16}$

Pada akhirnmya adalah salimg terkait bahwa penerapan sistem demokrasi dalam menjaga persatuan dan konstitusi serta penegakan hukumnya akan tercipta dengan baik manakala selalu dijalani dengan itikad baik dan niatan menjalankan fungsi pemerintahan demi kemashlahatan umat, bangsa dan negara RI.

\section{E. PENUTUP}

Disimpulkan, penerapan sistem demokrasi dalam konteks mempertahankan persatuan dan konstitusi harus mengedepankan dan memperhatikan semangat sumpah pemuda dan kepahlawanan yang direfleksikan dalam asas Pancasila, asas kekeluargaan, asas kedaulatan rakyat, asas pembagian kekuasaan dan asas negara hukum yang nantinya akan membentuk nasionalisme dan mencintai bangsa dan senantiasa konsisten dengan konstitusi negara.

Sedangkan sebagai saran, perlunya meningkatkan pemahaman makna kedaulatan negara serta persatuan bangsa yang telah dijamin secara yuridis dalam konstitusi agar masyarakat tidak terpengaruh oleh arus pengaruh globalisasi yang terjadi di Indonesia terlebih di era otonomi yang sangat rentan dengan berbagai konflik politik dan kepentingan-kepentingan yang bisa mengganggu stabilitas pemerintahan seperti proses pilkada, pemilu legislatif, dan sebagainya.

${ }^{15}$ Moh. Mahfud MD, Pergulatan Politik dan Hukum Di Indonesia, Yogyakarta : Gama media, 1999, hlm. $1-2$.

${ }^{16}$ Afan Gafar, Politik Indonesia Transisi Menuju Demokrasi, Yogyakarta : Pustaka Pelajar, 2002, hlm. $7-9$. 


\section{DAFTAR PUSTAKA}

\section{Buku}

Asshiddiqie, Jimly, 1994, Gagasan Kedaulatan Rakyat Dalam Konstitusi dan Pelaksanaannya di Indonesia, Jakarta: Intermasa.

Budiardjo, Miriam, 1980, Dasar-Dasar Ilmu Politik, Jakarta: Gramedia.

Gafar, Afan, 2002, Politik Indonesia Transisi Menuju Demokrasi, Yogyakarta : Pustaka Pelajar.

Kusnardi dan Harmaily Ibrahim, 1988, Pengantar Hukum Tata Negara, Jakarta : Pusat Studi HTN Fak. Hukum UI dan CV Sinar Bakti.

Kusumaatmadja, Mochtar, 1986, Pembinaan Hukum Dalam Kerangka Pembangunan Nasional, Bandung: Binacipta.

Mahfud MD, Moh., 1999, Hukum dan Pilar-Pilar Demokrasi, Yogyakarta: Gama Media.

Yogyakarta : Gama media.

Pito, Toni Adrianus 2006, Mengenal Teori-Teori Politik, Dari Politik Sampai Korupsi, Bandung: Nuansa.

Rahardjo, Satjipto, 2006, Ilmu Hukum, Bandung: Citra Aditya Bakti.

Nusantara.

Sidharta, Arief, 1999, Refleksi Tentang Struktur Ilmu Hukum, Bandung: Mandar Maju.

Soekanto, Soerjono dan Mustafa Abdullah, 1982, Sosiologi Hukum Dalam Masyarakat, Jakarta: CV Rajawali.

\section{Peraturan Perundang-undangan}

Undang-Undang Dasar NRI Tahun 1945.

Undang-Undang Nomor 39 Tahun 1999 tentang Hak Asasi Manusia. 
Ronny Winarno, Penerapan Sistem Demokrasi dalam ...

Undang-Undang Nomor 24 Tahun 2003 tentang Mahkamah Konstitusi.

Undang-Undang Nomor 32 Tahun 2004 tentang Pemerintahan Daerah.

Undang-Undang Nomor 8 Tahun 2011 tentang Perubahan atas Undang-Undang Nomor 24 Tahun 2003 tentang Mahkamah Konstitusi. 